\title{
Effect of Employees' Understanding on Risk Management Process on Risk Management: A Case Study in a Non-profit Organisation
}

\author{
Erlane K Ghani ${ }^{1}$, Nor Hamimah Nor Hassin ${ }^{1} \&$ Kamaruzzaman Muhammad ${ }^{1}$ \\ ${ }^{1}$ Faculty of Accountancy, Universiti Teknologi MARA, Malaysia \\ Correspondence: Erlane K Ghani, Faculty of Accountancy, Universiti Teknologi MARA, Malaysia.
}

Received: April 20, 2019

Accepted: May 7, 2019

Online Published: May 19, 2019

doi:10.5430/ijfr.v10n3p144

URL: https://doi.org/10.5430/ijfr.v10n3p144

\begin{abstract}
Purpose: This study examines the effect of employees' understanding of risk management process on knowledge on risk management in a non-profit organisation. Specifically, this study examines the effect of employees' understanding of risk identification, risk assessment and analysis and, risk control and monitoring on their knowledge on risk management.

Design/Methodology/Approach: This study used questionnaire survey on 80 employees of various levels in a non-profit organisation.

Findings: This study shows that the most of the employees felt that they have a poor knowledge on risk management. The poor knowledge on risk management is attributed by the all three determinants in this study namely, understanding risk identification, risk assessment and analysis and, risk control and monitoring process on knowledge on risk management.

Practical Implications: The findings provide indication that non-profit organisations need to provide awareness programs to their employees in increasing their knowledge on risk management. The findings of this study is essential to the managements to ensure that their employees are well informed and understand risk management and subsequently, take necessary control to reduce risks.

Originality/Value: This study provides further understanding on the importance of understanding risk management process on performance.
\end{abstract}

Keywords: employees, risk management, non-profit organisation, Malaysia

JEL code: M40, M41

\section{Introduction}

During the 1997 East Asian financial crisis, one-tenth of Bursa Malaysia's 800 publicly listed organisations have cited poor risk management as a major contributor to their crisis failures and poor corporate governance (Jin, 2001). This has caused severity in corporate governance problems in the Bursa-listed organisations. The growing complexity of the economic environment has attracted considerable attention from different stakeholders to organisational risk management practices. Risk information allows relevant stakeholders to evaluate management's efficiency in addressing uncertainties and opportunities (Lajili \& Zeghal, 2005). Arguably, it is important that the management reveals adequate information on the different types of risks faced by their organisation. The importance of adequate risk information has led many researchers to examine information adequacy in meeting the needs of different stakeholders (Abraham \& Cox, 2007; Lajili \& Zehgal, 2005; Oliveria, Rodrigues \& Craig, 2011).

A recent article entitled "Increasing risk awareness of mission- critical goals of non- profit organisations" published by the American Institute of Certified Public Accountants (AICPA, 2011 p.20) states, "Increased risk awareness is becoming an expected best practice in the organisation's overall governance. Knowing that organisations must take risks if they want to pursue their mission, managers now see the strategic value of being better informed about those risks that could have a positive or negative impact on their mission objectives". Due to their unique characteristics, non-profit organisations face various types of risks, such as non-profit maximisation, types of funding and voluntary employees. These characteristics expose the non-profit organisations to unique risks that may differ from risks faced by other type of organisations (The Our Community Team, 2005). 
This study aims to examine the effect of employees' understanding of risk management process on their knowledge in a non-profit organisation. Specifically, this study examines whether employees' understanding on risk identification, risk assessment and analysis and, risk control and monitoring process on their knowledge on risk management. The findings of this study is essential to the management to assess whether the employees of the non-profit organisation are well informed and understand risk management and subsequently, take necessary control to reduce risk. The next section presents the literature review in Section 2. This is followed by Section 3 that presents the research design and Section 4 that presents the research framework and hypotheses development. Section 5 presents the results and discussion. The last section, Section 6 summarises and concludes this chapter.

\section{Literature Review}

Risk management is an integral part of all core business functions and should be considered and treated as such. Risk management at all levels of the organisation should be fully integrated into operational and management processes and driven from top to bottom. For risk management and the successful operation of the business is essential to regularly review the risks and update the definition and methods. A traditional risk management process in accordance with the International Organisation for Standardisation guidelines (ISO 31000:2018) involves three key steps namely, risk identification, risk assessment and analysis, and risk control and monitoring process.

Risk identification can be defined as an analytical process that constantly identifies, evaluates and categorizes the initial importance of the risks associated with construction projects (Al-Bahar \& Crandall, 1990) and the interrelationships that exist between these risks (Liu, Zhao \& Yan, 2016). It refers to the process of identifying and classifying risks that may affect the project and documenting these risks. Risk identification is important as it can assist an organisation to identify the best and most important input data; to have a better understanding on process and to identify the risks. Ultimately, risk identification provides information for decision-makers (Rostami, 2016). Therefore, this study develops the following research hypothesis:

H1: Employees' understanding of risk identification process significantly influences their knowledge on risk management.

Risk assessment is the procedure for critical assessment of potential risks, arranging them according to their importance and allowing the management team to select the important ones (El-Sayegh \& Mansour, 2015; Rau, 2017; Khan., Hassan \& Marimuthu, 2017; Dike \& Dike, 2017; Wadmany, \& Melamed, 2018; Zhu \& Chen, 2018; CHE \& Sundjo, 2018). Risk assessment determines the probability and impact descriptions and the risk rating index. To determine which consequences would lead to an extreme risk or a general low risk would create an appropriate control method. It is advisable to develop methods for risk management and to define the level and consequences of the risks. The evaluation process may involve decision-making, particularly in the case of high or extreme risk levels which involves analysing the probability and consequences of each identified risk and determining which risk factors may have the greatest effect and should therefore be given priority as to how they should be managed. On the other hand, risk analysis is the most important risk management procedure as it involves evaluating chances of a risk event and its results on the objectives of a project (Thomas, 2006; Adisa., Adeoye, \& Okunbanjo, 2016; Chang'ach, 2018). It is used to assess risk by separating unnecessary events, chances of the unwanted events and size of these events (KarimiAzari, Mousavi, Mousavi \& Hosseini, 2011), which is the transitional process between risk identification and the management. It includes qualitative and quantitative uncertainty in order to assess the potential risk effects. Risk evaluation and analysis are generally considered to be one of the most difficult tasks. Therefore, the following research hypothesis is developed:

H2: Employees' understanding of risk assessment and analysis process significantly influences their knowledge on risk management.

Risk control and monitoring are important in the financial institution as they are used to ensure that the organisation's risk management practices are in line with the objectives of the organisation and to help the management of the organisation to detect error at an early stage (Hassan, 2009; Meghouar, 2014; Kamyab, 2014; Nazri., Hamid, \& Muslim, 2014; Paul, 2014; Baslom \& Tong, 2019; Al-Taweel, 2015; Ishak, 2016; Klapproth \& Martin, 2018; Obi \& Okekeokosisi, 2018). Rahman (2011) pointed out that credit monitoring consists of periodic reviews, ratings and audits to warn a borrower about his early financial health. The effects of institutional monitoring on performance have previously been investigated by Allen, Carletti and Marquez (2008), Besanko and Kanatas (1993), and Dewatripont and Tirole (1994). Their findings have demonstrated that bank monitoring improves the expected return on projects and thereby improves organisational performance. For the purpose of continuous growth and subsequent references, an organisation would further expand the risk management process to the monitoring and post-process assessment stage. Makiyan (2008) believed that good internal controls could reduce mismanagement and attract 
market trust. Therefore, this study develops the following research hypothesis:

H3: Employees' understanding of risk control and monitoring process significantly influences their knowledge on risk management.

\section{Research Design}

\subsection{Sample Selection}

The employees of a non-profit organisation are selected as the sample in this study. The respondents came from various departments that could generally be classified as a finance department or deal with transactions, operations, customer service or tasks related to customer technical support, sales or tasks. The respondents came from various levels of non-executive to management level since they are directly involved in a business unit, function, or process in the non-profit organisation. This is consistent with Pearce and Gray and Larson (2006) and Rejda (2011) that stated risk management does not eliminate risk but provides a platform for managing risk by minimising threats, maximising opportunities and optimising goals. This study follows Stevens' (2012) guideline that states a sample size can be determined using 15 participants per predictor (independent variable) or at least 45 participants. This study has gathered a total of 80 respondents thus, complying with Steven's guideline.

\subsection{Research Instrument and Data Collection}

This study utilises the questionnaire survey. The questions are adopted from previous studies with some modifications to suit the context of this study. Al-Tamimi and Al-Mazrooei, (2007) and Abu Hussain and Al-Ajmi, (2012) identified several scenarios that proxy the knowledge on risk management involvement of employees at their working environment. There are three parts in the questionnaire. The first part of the questionnaire requests the respondents to provide demographic information such as gender, age, work experience, organisational tenure, education and position within the organisation. This is followed by all four variables studied in this research, namely the knowledge on risk management, risk identification process, risk assessment and analysis process and risk control and monitoring process. The second part of the questionnaire requests the respondents to provide their perception of risk management and this second part aims to measure their knowledge on risk management. The respondents are asked to complete six questions using a 5-point scale ranging from ' 1 ' as strongly disagree to ' 5 ' as strongly agree. The third part requests the respondents to provide their understanding of the risk identification process, risk assessment and analysis process and, risk control and monitoring process in order to measure their level of knowledge on risk management. The respondents are requested to complete 20 questions in this section using a 5 -point scale ranging from ' 1 ' as strongly disagree to ' 5 ' as strongly agree.

The questionnaire survey was conducted via Google's online survey, electronic mail and a direct face- to- face approach over a period of 6 months. A set of questionnaire consisting the cover letter explaining the purpose of the study and details of the researchers and the questionnaire survey were provided to each respondent. In addition, the link to the Google online survey address was also distributed via WhatsApp application and electronic mail, making it easier for the respondents to respond to the questionnaire.

\section{Results and Discussion}

\subsection{Knowledge on Risk Management}

Table 1 presents the descriptive statistics of risk management. The results show a low mean score for 3.51 overall dependent variables. The items with the lowest mean score are familiar with ISO 31000, which is only 2.71 . Unlike other ISO certifications, ISO 31000 serves as a reference guideline and an organisation is therefore not certified with ISO 31000. Only a person with a risk job knows this policy. Majority of the respondents also disagree that they have a common knowledge with an average score of 3.23 regarding risk management. It appears that they still need more knowledge related to risk management. The highest mean score (4.03) for understanding risk management would be 'Managing risk is important to the performance and success' with a maximum value of 5 answered by the respondents.

Table 1. Descriptive statistics on risk management

\begin{tabular}{llllll}
\hline List of Construct and Measures & $\mathrm{N}$ & Minimum & Maximum & Mean & SD \\
\hline Skewness $=.089$ & & & & & \\
Kurtosis $=-.050$ & 80 & 3 & 5 & 3.71 & .679 \\
1. Heard about risk management & 80 & & & \\
\hline
\end{tabular}




\begin{tabular}{llllll}
\hline 2. Familiar with ISO 31000 & 80 & 1 & 5 & 2.71 & 1.070 \\
\hline 3. Common knowledge & 80 & 2 & 5 & 3.23 & .693 \\
\hline 4. Responsibility for risk management clearly set out & 80 & 2 & 5 & 3.51 & .636 \\
\hline 5. Managing risk is important & 80 & 2 & 5 & 4.03 & .763 \\
\hline 6. Application of risk management & 80 & 2 & 5 & 3.90 & .722 \\
\hline Valid N (listwise) & 80 & & & & \\
\hline TOTAL & & & & \\
\end{tabular}

\subsection{Risk Identification}

Table 2 presents the descriptive statistics using the perceived pressure variable. The results show that the mean score is 3.51 which indicate that most of the respondents have low knowledge on risk assessment and analysis. The lowest mean score is 3.25 where the maximum value is 5 . This indicates that the majority of the respondents perceive themselves as having difficulties to prioritize the main risk. The highest mean score is 3.72 where their non-profit organisation must be aware of the strengths and weaknesses of the risk management system of competitors with maximum value of 5 and minimum value of 1 .

Table 2. Descriptive statistics of risk identification

\begin{tabular}{|c|c|c|c|c|c|}
\hline List of Construct and Measures & $\mathrm{N}$ & Minimum & Maximum & Mean & SD \\
\hline \multicolumn{6}{|l|}{ Skewness $=-.043$} \\
\hline \multicolumn{6}{|l|}{ Kurtosis $=.458$} \\
\hline 1. Systematic Risk Identification & 80 & 2 & 5 & 3.41 & .669 \\
\hline 2. Difficult to prioritise the main risk & 80 & 1 & 5 & 3.25 & .771 \\
\hline 3. Changes in risk are identified & 80 & 2 & 5 & 3.51 & .675 \\
\hline 4. Awareness of risk management system & 80 & 1 & 5 & 3.72 & .914 \\
\hline 5. Develop and applied procedure & 80 & 2 & 5 & 3.45 & .710 \\
\hline $\begin{array}{l}\text { 6. Always take shariah compliance issues in } \\
\text { identifying risk }\end{array}$ & 80 & 2 & 5 & 3.69 & .789 \\
\hline Valid N (listwise) & 80 & & & & \\
\hline TOTAL & & & & 3.51 & \\
\hline
\end{tabular}

\subsection{Risk Assessment and Analysis Process}

The descriptive analysis and normality test on risk assessment and analysis process are captured in Table 3. The mean score is 3.61 indicates that most of the respondents have low understanding of risk assessment and analysis. The measure with the lowest mean score of 3.43 with the maximum value of 5 relates with the risk being assessed by using the quantitative analysis methods (i.e. score value), while the highest mean score of 3.79 relates to risk being assessed by using qualitative analysis methods (i.e. high, moderate and low).

Table 3. Descriptive statistics of risk assessment and analysis

\begin{tabular}{llllll}
\hline List of Construct and Measures & $\mathrm{N}$ & Minimum & Maximum & Mean & SD \\
\hline $\begin{array}{l}\text { Skewness }=.192 \\
\text { Kurtosis }=.622\end{array}$ & & & & & \\
1. Likelihood of occurring risk & 80 & 2 & 5 & 3.66 & .615 \\
\hline 2. Assessed by quantitative analysis & 80 & 1 & 5 & 3.43 & .883 \\
\hline 3. Assessed by qualitative analysis & 80 & 2 & 5 & 3.79 & .650 \\
\hline 4. Analyse the opportunity & 80 & 2 & 5 & 3.59 & .688 \\
\hline
\end{tabular}




\begin{tabular}{llllll}
\hline 5. Response to analysis risk & 80 & 2 & 5 & 3.60 & .565 \\
\hline 6. Prioritise risk & 80 & 2 & 5 & 3.69 & .628 \\
\hline 7. Prioritize risk treatment & 80 & 2 & 5 & 3.59 & .630 \\
\hline 8. Shariah application on risk & 80 & 2 & 5 & 3.53 & .763 \\
\hline Valid N (listwise) & 80 & & & & \\
\hline TOTAL & & & & 3.61 & \\
\hline
\end{tabular}

\subsection{Risk Control and Monitoring}

Table 4 shows the descriptive analysis and the risk control and monitoring normality test, showing the minimum and maximum value, the mean score and standard deviation as well as the non- missing value $\mathrm{N}$, which measures the risk assessment and analysis variable. The results show that the mean score is 3.63 which indicates that most of the respondents have low understanding of risk control and monitoring. The measure with the lowest mean score of 3.55 with the maximum value of 5 relates with the level of control implemented is appropriate for risk, while the highest mean score of 3.80 relates to monitoring the effectiveness of risk management being an integral part of routine reporting.

Table 4. Descriptive statistic of risk control and monitoring

\begin{tabular}{|c|c|c|c|c|c|}
\hline List of Construct and Measures & $\mathrm{N}$ & Minimum & Maximum & Mean & SD \\
\hline \multicolumn{6}{|l|}{ Skewness $=-.043$} \\
\hline \multicolumn{6}{|l|}{ Kurtosis $=-.059$} \\
\hline 1. Monitor the risk effectiveness & 80 & 3 & 5 & 3.80 & .644 \\
\hline 2. Appropriate level of control & 80 & 2 & 5 & 3.55 & .745 \\
\hline 3. Changes in risk are identified & 80 & 2 & 5 & 3.60 & .608 \\
\hline 4. Reporting and communication & 80 & 2 & 5 & 3.55 & .593 \\
\hline 5. Effectiveness existing control & 80 & 2 & 5 & 3.66 & .635 \\
\hline $\begin{array}{l}\text { 6. Always take shariah compliance } \\
\text { issues in monitoring risk }\end{array}$ & 80 & 2 & 5 & 3.63 & .735 \\
\hline Valid N (listwise) & 80 & & & & \\
\hline TOTAL & & & & 3.63 & \\
\hline
\end{tabular}

\subsection{Simple Linear Regression Model}

Table 5 presents the results of the simple linear regression model. The results indicate that variable risk identification significantly influences the employees' knowledge on risk management since the value is 0.000 which is less than 0.05 ( $\mathrm{p}<0.05)$. The coefficient of correlation, $(\mathrm{r}=0.688)$, suggests that there is positive low relationship between risk identification and knowledge on risk management. Risk assessment and analysis shows significance as the value is less than $0.05(\mathrm{p}<0.05)$. The coefficient of correlation, $(\mathrm{r}=0.569)$, indicates that there is positive low relationship between risk assessment and analysis and knowledge on risk management. It is also similar with the risk control and monitoring variable, where the value is 0.000 , which is less than $0.05(\mathrm{p}<0.05)$. The coefficient of correlation, $(\mathrm{r}=0.616)$, also indicates that there is positive low relationship between employees' understanding on risk control and monitoring and knowledge on risk management.

Table 5. Pearson correlation coefficient matrix and level of significance

\begin{tabular}{llllll}
\hline Variable & & DV & IV1 & IV2 & IV3 \\
\hline \multirow{2}{*}{ DV } & Pearson Correlation & 1 & $.688^{* *}$ & $.569^{* *}$ & $.616^{* *}$ \\
\cline { 2 - 6 } & Sig. (2-tailed) & & .000 & .000 & .000 \\
\hline
\end{tabular}




\begin{tabular}{llllll}
\hline & $\mathrm{N}$ & 80 & 80 & 80 & 80 \\
\hline IV1 & Pearson Correlation & $.688^{* *}$ & 1 & $.649^{* *}$ & $.719^{* *}$ \\
\cline { 2 - 6 } & Sig. (2-tailed) & .000 & & .000 & .000 \\
\cline { 2 - 6 } & $\mathrm{N}$ & 80 & 80 & 80 & 80 \\
\hline IV2 & Pearson Correlation & $.569^{* *}$ & $.649^{* *}$ & 1 & $.809^{* *}$ \\
\cline { 2 - 6 } & Sig. (2-tailed) & .000 & .000 & & .000 \\
\cline { 2 - 6 } & $\mathrm{N}$ & 80 & 80 & 80 & 80 \\
\hline IV3 & Pearson Correlation & $.616^{* *}$ & $.719^{* *}$ & $.809^{* *}$ & 1 \\
\hline \multirow{2}{*}{} & Sig. (2-tailed) & .000 & .000 & .000 & \\
\hline ** Correlation is significant at the 0.01 level (2-tailed) & 80 & 80 & 80 & 80 \\
\hline
\end{tabular}

**. Correlation is significant at the 0.01 level (2-tailed)

The above variables are defined as: DV $=$ Knowledge on Risk Management; IV1 = Risk Identification; IV2 = Risk Assessment and Analysis, IV3 = Risk Control and Monitoring.

\subsection{Testing Research Hypotheses}

Table 6 presents the results explain the influence of risk identification on knowledge on risk management. $\mathrm{H}_{1}$ suggests that the results between employees' knowledge on risk identification and knowledge on risk management, the significance value shows that at $95 \%$ confidence level, variable risk identification process is significant to influence knowledge on risk management since the value is 0.000 which is less than $0.05(p=0.000, p<0.05)$. The 0.688 coefficient of correlation $(\mathrm{R}=0.688)$ and positive value of $\mathrm{B}_{0}\left(\mathrm{~B}_{0}=0.692\right)$ indicate that there is positive low relationship between employees' understanding on risk identification process and their knowledge on risk management. The results show that 0.473 coefficient of determination $\left(\mathrm{R}^{2}=0.473\right)$ infers that $47.3 \%$ of the total variation in knowledge on risk management can be explained by employees' understanding on risk identification process and the remaining $52.7 \%$ is explained by other factors. At 0.05 level of significance, with degree of freedom $d f$ of $79(\mathrm{~N}-2)$, the $t$-critical value is 2.000 while $t$-statistics value is 8.369 . At this instance, since the $t$-statistics value (8.369) is greater than $t$-critical value (2.000), null hypothesis is rejected. This study concludes that there is a positive significant relationship between employees' understanding of risk identification process and their knowledge on risk management. The p-value is also less than $0.05(\mathrm{p}<0.05)$ where null hypothesis is rejected. As such, $\mathrm{H}_{1}$ is supported. This study implies that there is significant linear relationship where the respondents' knowledge on risk management is influenced by their understanding of risk identification process.

Table 6. Regression analysis result for risk identification

\begin{tabular}{llllll}
\hline Variable & \multicolumn{6}{l}{ Understanding Risk Management } & \\
\cline { 2 - 6 } & Sig. & $\mathrm{R}$ & $\mathrm{R}^{2}$ & $\mathrm{~B}_{0}$ & $T$ \\
\hline Risk Identification & 0.000 & 0.688 & 0.473 & 0.692 & 8.369 \\
\hline $\begin{array}{l}\text { Risk Assessment } \\
\text { and Analysis }\end{array}$ & 0.000 & 0.324 & 0.324 & 0.633 & 6.110 \\
\hline Risk Identification & 0.000 & 0.616 & 0.380 & 0.653 & 6.910 \\
\hline
\end{tabular}

In addition, Table 6 also presents the significance value for variable risk assessment and analysis is 0.000 and this indicates that the variable is significant at $95 \%$ confident level as the value is less than $0.05(\mathrm{p}=0.000, \mathrm{p}<0.05)$. The 0.324 coefficient of correlation ( $R=0.324)$ and positive value of $\mathrm{B}_{0}\left(\mathrm{~B}_{0}=0.633\right)$ indicates that there is positive low relationship between risk assessment and analysis and knowledge on risk management. It is supported by $0.324 \mathrm{R}^{2}$ which indicates only $32.4 \%$ of risk assessment and analysis in understanding risk management. At 0.000 level of significance, with degree of freedom $d f$ of $79(\mathrm{~N}-2)$, the $t$-critical value is 2.000 while $t$-statistics value is 6.110 . At this instance, since the $t$-statistics value (6.110) is more than $t$-critical value (2.000), null hypothesis is rejected. This study concludes that there is significant relationship between employees' understanding of risk assessment and 
analysis process and their knowledge on risk management. The $\mathrm{p}$-value is also less than $0.05(\mathrm{p}<0.05)$, where null hypothesis is rejected. As such, $\mathrm{H}_{2}$ is also supported; hence, the second objective is achieved. This research however also implies that there is a positive relationship between employees' understanding of risk assessment and analysis and knowledge on risk management.

Table 6 also points to the results that explain the influence of risk control and monitoring on knowledge on risk management. $\mathrm{H}_{3}$ suggests that the results between risk control and monitoring and understanding risk management, the significance value shows that at $95 \%$ confidence level, variable risk control and monitoring is significant to influence knowledge on risk management since the value is 0.000 which is less than $0.05(\mathrm{p}=0.000, \mathrm{p}<0.05)$. The 0.616 coefficient of correlation $(\mathrm{R}=0.616)$ and positive value of $\mathrm{B}_{0}\left(\mathrm{~B}_{0}=0.653\right)$ indicates that there is positive low relationship between risk management process and understanding risk management. The results show 0.380 coefficient of determination $\left(\mathrm{R}^{2}=0.380\right)$ infers that $38.0 \%$ of the total variation in understanding risk management can be explained by employees' understanding of risk control and monitoring process and the remaining $62.0 \%$ is explained by other factors. At 0.05 level of significance, with degree of freedom $d f$ of $79(\mathrm{~N}-2)$, the $t$-critical value is 2.000 while $t$-statistics value is 6.910 . At this instance, since the $t$-statistics value (6.910) is greater than $t$-critical value (2.000), null hypothesis is hence rejected. This research concludes that there is a positive significant relationship between employees' understanding of risk control and monitoring process and their knowledge on risk management. The p-value is also less than 0.05 ( $\mathrm{p}<0.05)$, where null hypothesis is rejected. As such, $\mathrm{H}_{3}$ is supported. This research also implies that there is significant linear relationship where the respondents' knowledge on risk management is influenced by their understanding of risk control and monitoring process.

\section{Summary and Conclusion}

This study examines the effect of the employees' understanding on the risk management process on their knowledge on risk management. Based on the findings shown in this study, this study shows that the employees have limited understanding on submission of risk register as their knowledge on risk calculation is not satisfactory. The employees also have limited understanding of the importance of risk in an organisation, plus they do not see the need to familiarize themselves with risk management. In addition, the employees seem to have a difficult time understanding risk, risk management, risk management process.

This study is not without limitations. First, the scope of this study is limited to only one non-profit organisation. Secondly, the number of respondents is also significantly small, as a large number of respondents would lead to a more concrete analysis and results. Another limitation in this study is that it covers only the three main steps in the risk management process. It is therefore suggested that more respondents to be involved in the future. This will allow the researchers to generalize the entire population of selected respondents. However, the limitations of this research do not affect the results and results of this research but are recognised to highlight future research opportunities.

\section{Acknowledgement}

We wish to thank the Institute of Quality and Knowledge Advancement and Accounting Research Institute, Universiti Teknologi MARA for their support and funding.

\section{References}

Abu Hussain, H., \& Al-Ajmi, J. (2012). Risk management practices of conventional and Islamic banks in Bahrain. The Journal of Risk Finance, 13(3), 215-239. https://doi.org/10.1108/15265941211229244

Adisa, M. K., Adeoye, A. O., \& Okunbanjo, O. I. (2016). The impact of entrepreneurship orientation on entrepreneurs compensation in Nigeria. International Journal of Economics, Business and Management Studies, 3(3), 102-116.

Al-Bahar, J. F., \& Crandall, K. C. (1990). Systematic risk management approach for construction projects, J. Constr. Eng. M., 116, 533-46. https://doi.org/10.1061/(ASCE)0733-9364(1990)116:3(533)

Allen, F., Carletti, E., \& Marquez, R. (2008). Credit market competition and capital regulation. Wharton Working Paper Series (No. RHS-06-037). https://doi.org/10.2139/ssrn.813066

Al-Tamimi, H. H., \& Al-Mazrooei, F. M. (2007). Banks Risk Management: A Comparison Study of UAE National and Foreign Banks. Journal of Risk Finance, 8(4), 394-396. https://doi.org/10.1108/15265940710777333

Al-Taweel, L. M. (2015). Measuring the Gap Between the Syrian Accounting Qualifications and the International Accounting Education Based on IES 2 and IES 3. The Economics and Finance Letters, 2(3), 24-34. https://doi.org/10.18488/journal.29/2015.2.3/29.3.24.34 
Baslom, M. M. M., \& Tong, S. (2019). Knowledge Management (KM) Practices in Education and Learning: Establishing a Knowledge Economy in Saudi Arabia. Humanities and Social Sciences Letters, 7(1), 1-9. https://doi.org/10.18488/journal.73.2019.71.1.9

Besanko, D., \& Kanatas, G. (1993). Credit market equilibrium with bank monitoring and moral hazard. The Review of Financial Studies, 6(1), 213-232. https://doi.org/10.1093/rfs/6.1.213

Chang'ach, J. K. (2018). An historical trajectory of the economic transformation of the southern Keiyo community in Kenya. Global Journal of Social Sciences Studies, 4(2), 52-69. https://doi.org/10.20448/807.4.2.52.69

Che, G. N., \& Sundjo, F. (2018). Determinants of Female Labour Force Participation in Cameroon. International Journal of Applied Economics, Finance and Accounting, 3(2), 88-103. https://doi.org/10.33094/8.2017.2018.32.88.103

Dewatripont, M., \& Tirole, J. (1994). The prudential regulation of banks (No. 2013/9539). ULB-Universite Libre de Bruxelles.

Dike, V. E., \& Dike, N. I. (2017). Youth Development and Conflict Resolution in Nigeria: Assessment and Intervention Strategies. Asian Journal of Education and Training, 3(1), 30-42. https://doi.org/10.20448/journal.522/2017.3.1/522.1.30.42

El-Sayegh, S. M., \& Mansour, M. H. (2015). Risk assessment and allocation in highway construction projects in the UAE. Journal of Management, Engineering, 04015004. https://doi.org/10.1061/(ASCE)ME.1943-5479.0000365

Gray, C. F., \& Larson, E. W. (2006). Project management: The managerial process (3rd ed.). New York, NY: Irwin/McGraw-Hill.

Ishak, K. (2016). A Factor Analysis Approach Towards a Study of the Factors Affecting Students' Choice of Higher Education Institution: A Case Study of a Private Institution (Twintech International University College of Technology). Journal of Social Economics Research, 3(2), 21-30. https://doi.org/10.18488/journal.35/2016.3.2/35.2.21.30

Jin, F. E. (2001). Poor risk management causes ailing firms' downfall. Business Times.

Kamyab, S. H. (2014). The Entrepreneurship, Knowledge Spillover and Economic Growth. International Journal of Sustainable Development \& World Policy, 3(2), 45-54.

KarimiAzari, A., Mousavi, N., Mousavi, S. F., \& Hosseini, S. (2011). Risk assessment model selection in construction industry. Expert Syst. Appl., 38, 9105-11. https://doi.org/10.1016/j.eswa.2010.12.110

Khan, H., Hassan, R., \& Marimuthu, M. (2017). Diversity on Corporate Boards and Firm Performance: An Empirical Evidence from Malaysia. American Journal of Social Sciences and Humanities, 2(1), 1-8. https://doi.org/10.20448/801.21.1.8

Klapproth, F., \& Martin, R. (2018). Predictors of the Drop in School Marks in Secondary School: Evidence for Effects of Students' Socio-Demographic Background. International Journal of Education and Practice, 6(3), 147-166. https://doi.org/10.18488/journal.61.2018.63.147.166

Liu, J., Zhao, X., \& Yan, P. (2016). Risk paths in international construction projects: Case study from Chinese contractors. J. Constr. Eng. M., 142, 05016002. https://doi.org/10.1061/(ASCE)CO.1943-7862.0001116

Makiyan, S. N. (2008, September-December). Risk management and challenges in Islamic Banks. Journal of Islamic Economics, Banking and Finance, 4(3), 19.

Meghouar, H. (2014). French Students of Maghreb Background and Entrepreneurship. International Journal of Business, Economics and Management, 1(7), 125-135.

Nazri, M. N. M., Hamid, Z., \& Muslim, H. (2014). The Inclination of Information and Communication Technology (ICT) Students Towards Entrepreneurship. International Journal of Management and Sustainability, 3(8), 484-492.

Obi, M. N., \& Okekeokosisi, J. (2018). Extent of Implementation of National Entrepreneurship Curriculum in Tertiary Institutions as Perceived by Educators. American Journal of Education and Learning, 3(2), 108-115. https://doi.org/10.20448/804.3.2.108.115

Paul, M. (2014). Ensuring Quality Provision of Education for All: Discovering Challenges Faced by Teachers of Students with Learning Disabilities in Regular Primary Schools in Masvingo District. International Journal of 
Public Policy and Administration Research, 1(1), 26-37.

Rau, H. (2017). Student-Centered Learning: Moving Towards Mass-Customization in Higher Education. International Journal of Educational Technology and Learning, 1(1), 37-50. https://doi.org/10.20448/2003.11.37.50

Rejda, G. E. (2011). Introduction to risk management and insurance (11th ed.). Upper Saddle River, NJ: Prentice Hall.

Rostami, A. (2016). Tools and techniques in Risk identification: a research within SMEs in the UK construction industry. Universal Journal of Management, 4(4), 203-210. https://doi.org/10.13189/ujm.2016.040406

Wadmany, R., \& Melamed, O. (2018). New Media in Education" MOOC: Improving Peer Assessments of Students' Plans and Their Innovativeness. Journal of Education and e-Learning Research, 5(2), 122-130. https://doi.org/10.20448/journal.509.2018.52.122.130

Zhu, C., \& Chen, L. (2018). An Analysis of the Development of China's Commercial Banks under the Structural Reform of the Supply Side. Journal of Accounting, Business and Finance Research, 4(1), 1-8. https://doi.org/10.20448/2002.41.1.8 